\title{
COMPETENCY TRAINING: MEASURING THE DETERMINANTS OF INTENTION
}

\author{
Nurhidayati $^{1}$, Aprih Santoso ${ }^{2}$ and Suryanto ${ }^{3}$ \\ ${ }^{1,2}$ Economics Faculty, Semarang University \\ ${ }^{3}$ Department of Business Administration, Padjajaran University \\ E-mail: nurhidayati@usm.ac.id ${ }^{1}$, aprihsantoso@usm.ac.id²*,suryanto@unpad.ac.id ${ }^{3}$
}

\begin{abstract}
The research aims to empirically analyze the effects of motivation, perceived costs, perceived convenience and perceived usefulness on student interest in participating in competency training. The research object is students of the Management Study Program, Faculty of Economics, Semarang University. The number of samples was 96 students. The sampling technique used a systematic random method, namely students of the Management Study Program, Faculty of Economics. Technique data analysis used multiple regression and classical assumption tests as well as hypothesis testing ( $\mathrm{t}$ test and $\mathrm{F}$ test). The results showed that: (1) Motivation has a positive and significant effect on interest in participating in competency training. (2) Training costs have a negative effect on interest in participating in competency training. (3) Perception of convenience has a positive effect on interest in participating in competency training. (4) Perceived benefits have a positive effect on interest in participating in competency training. The conclusion is that motivation, perceived convenience and benefits have a positive and significant effect on the intention to attend competency training, while the training costs have negative results. The implication: (1) The quality of the training needs to be improved, namely by using a lot of case study questions and practice questions. (2) The material is kept as simple as possible so that it is easily understood by the trainees. (3) Cooperating with institutions that issue competency training tests.
\end{abstract}

Key words: motivation; ease of use; usefulness; competency

\section{PELATIHAN KOMPETENSI: MENAKAR DETERMINAN MINAT}

\begin{abstract}
ABSTRAK. Penelitian bertujuan menganalisis secara empiris efek motivasi, persepsi biaya, persepsi kemudahan dan persepsi kemanfaatn terhadap minat mahasiswa mengikuti pelatihan kompetensi. Obyek penelitian adalah mahasiswa Program Studi Manajemen Fakultas Ekonomi Universitas Semarang. Jumlah sampel sebanyak 96 mahasiswa. Teknik pengambilan sampel menggunakan metode acak sistematis yaitu mahasiswa Program Studi Manajemen Fakultas Ekonomi Teknik analisis data menggunakan regresi berganda dan uji asumsi klasik serta uji hipotesis (uji t dan uji F). Hasil penelitian menunjukkan bahwa: (1) Motivasi berpengaruh positif dan signifikan terhadap minat mengikuti pelatihan kompetensi. (2) Biaya pelatihan berpengaruh negatif terhadap minat mengikuti pelatihan kompetensi. (3) Persepsi kemudahan berpengaruh positif terhadap minat mengikuti pelatihan kompetensi. (4) Persepsi manfaat berpengaruh positif terhadap minat mengikuti pelatihan kompetensi. Kesimpulannya adalah motivasi, persepsi kemudahan dan manfaat berpengaruh positif dan signifikan terhadap niat mengikuti pelatihan kompetensi sedangkan biaya pelatihan memperoleh hasil yang negatif. Implikasinya : (1) Kualitas Pelatihan perlu ditingkatkan yaitu dengan menggunakan banyak soal soal studi kasus dan praktek. (2) Materi dibuat sesederhana mungkin sehingga mudah dipahami oleh peserta pelatihan. (3) Bekerja sama dengan lembaga yang mengeluarkan uji pelatihan kompetensi.
\end{abstract}

Kata kunci: motivasi; kemudahan; kemanfaatan; kompetensi

\section{INTRODUCTION}

Human resources (HR) is a very important factor that cannot be separated from an organization, both institutions, and companies. HR is also the key that determines the company's development. In essence, human resources in the form of humans are employed in an organization as movers, thinkers, and planners to achieve the goals of the organization (Aidha, 2016). This development needs to be carried out by the Indonesian people, especially the younger generation when taking academic education because students are intellectuals who have a role not only for themselves but also for society, the nation and the state. To prepare human resources with high quality and competitiveness following the vision of Semarang University to produce professional and civilized and
Indonesian resources, with information technology insight and sustainable development that can compete both nationally and globally, then Semarang University, especially the Economics Faculty, holds training and competency test. This can be used maximally by students to develop themselves, not just participating in academic activities or studying in the classroom. The Economics Faculty requires Management Study Program students to take at least one of two competency training : business feasibility studies or e-commerce show on table 1.

Although at least one training required by management students, it turns out that not as many accounting students take competency training. This is because management students still have the opinion that there are not many benefits to be obtained from participating in training so that as a 
result, management students' interests are smaller than those of accounting students. Whereas in management science there are also many training offerings. Many factors make students interested in obtaining competency certificates, including motivation, perceptions of training costs, perceptions of ease of use, and usability. This shows that the intention of management students is smaller than that of accounting students.

Table 1. Participants of Management Student Competency Training

\begin{tabular}{ccccc}
\hline Year & $\begin{array}{c}\text { Amount of } \\
\text { Student }\end{array}$ & E-Commerce & $\begin{array}{c}\text { business } \\
\text { feasibility } \\
\text { studies }\end{array}$ & $\%$ \\
\hline $2018(1)$ & 3348 & 443 & 100 & 16,54 \\
$2018(2)$ & 2996 & 339 & 67 & 13,55 \\
$2019(1)$ & 3167 & 301 & 47 & 10,98 \\
\hline \multicolumn{4}{c}{ Source: Secondary data that has been processed, 2019 }
\end{tabular}

According to Agarwal \& Karahanna (2000) intention is a desire someone to do a certain behavior. Someone will do a behavior if have a desire or intention to do so. Intention too can indicate doing a behavior in the future and repeat it on later. Previous research results show that (intention) is a good predictor of behave the truth (Vijayasarathy, 2003). Many factors make a student intentioned in obtaining a competency certificate including : motivation (Baloglu \& Mc Cleary, 1999; Standage, et. al, 2003; Huang \& Hsu, 2009; Indriyani, 2018; Setyawan \& Iswanaji, 2019), perception of the cost (Gul, et. al. 1989; Eline, 2009; Berlinasari \& Erawati, 2017), perception of ease of use (Davis, 1989; Nysveen et al., 2005; Langelo, 2013; Alharbi \& Drew, 2014; Witami \& Suartana, 2019; Prathama \& Sahetapy, 2019), and usefulness (Davis, 1989; Nysveen, et al., 2005; Langelo, 2013; Lu, et. al. 2009; Lou, et.al. 2005; Alharbi \& Drew, 2014; Witami \& Suartana, 2019).

Kotler \& Keller (2016), "customer buying decision is all their experience in learning, choosing, using, even disposing of a product". It means consumer purchase intention is all their experiences in learning, selecting, using, and even not using the product. Ajzen (1991), intention is the individual's intention to show a behaviour These statements indicate that intention is characterized by preference, like, or love as a form of expression for something that is wanted.

Intention is influenced by several factors including motivation (Standage, et. al, 2003; Baloglu \& Mc Cleary, 1999; Huang \& Hsu, 2009; Indriyani, 2018; Setyawan \& Iswanaji, 2019). Motivation is encouragement in a person to do or work the best on an activity or task to reach achievement (Mangkunegara, 2016). Motivation as a set of energetic forces that originate both within and beyond individual beings, to initiate behavior related work, and to determine for, direction, intensity, and time (Lundberg, et.al, 2009). Different results have been studied by Widyanto \& Fitriana (2016) it states that motivation does not affect intention.

So it can be concluded that motivation is something that encourages someone to do something, the motivation of an individual can arise from within the individual (intrinsic motivation) and can arise from outside the individual (extrinsic motivation). Apart from motivation, other factors influence intention, namely cost perception. Gul, et.al (1989); Eline (2009); Sapitri \& Yaya (2015); Berlinasari \& Erawati (2017) states that cost perception affects intention.

Mulyadi (2016), costs are the sacrifices of economic resources measured in units of money, which have occurred, are happening or are likely to occur for certain purposes, while Simamora (2015), costs are cash or cash equivalent value sacrificed for goods or services that are expected to provide current or future benefits to the organization. Gul, et. al. (1989); Sapitri \& Yaya (2015); Berlinasari \& Erawati (2017); Denziana \& Febriani (2017) which shows that costs harm intention. It is different from Zyl (2011); Katti \& Mutmainah's (2014) research, that the cost of PPAk education does not significantly affect the intention of students in attending PPAk education.

The perceived ease of use also affects intention (Davis, 1989; Nysveen et al., 2005; Langelo, 2013; Alharbi \& Drew, 2014; Prathama \& Sahetapy, 2019; Witami \& Suartana, 2019). If someone believes that the infomation system is easy to use, then he will use it. Conversely, if someone believes that the information system is not easy to use, then he will not use it.

On the other hand, the perceived usefulness also affects intention (Davis, 1989; Nysveen et al., 2005; Langelo, 2013; Alharbi \& Drew, 2014; Witami \& Suartana, 2019). The existence of perceived usefulness can affect the purchase intention of a person when a consumer can feel it. The perceived usefulness has a direct impact on the goals of technology adoption.

This study is novelty, different and has advantages over previous similar studies because this study accommodates previous research suggestions and combines several independent variables from several previous studies whose results are contradictory as described above.

The research objective is to examine the effect of motivation, cost perception, perceived ease of use, and perceived usefulness on student intention in participating in the competency test training. 


\section{Motivation}

Motivation is something that encourages someone to do something. The motivation of an individual can arise from within the individual (intrinsic motivation) and can arise from outside the individual (extrinsic motivation). According to Taylor's theory of motivation, the basic idea explains that a person (worker) will be willing to work well if the person believes that he will get a reward that is directly related to his work. This short explanation implies that a person's enthusiasm for work will decrease if the payment is delayed. General motivation is related to achieving all goals (Widyanto \& Fitriana, 2016). Hasibuan (2016), motivation is the provision of a driving force that creates a person's enthusiasm for work, so that they are willing to work together, work effectively, and integrated with all efforts to achieve satisfaction. Motivation is a psychological factor that shows individual intention to work, feeling satisfied and taking responsibility for the activity or occupation. Desire can be maximally achieved if motivation goes through a gradual cycle (Crompton, 1979; Surifah, et $\mathrm{al}, 2016$ ). The main benefit of motivation is to create work passion, so that work productivity increases. Meanwhile, the benefits of working with motivated people are: the job gets done properly. This means that the work is completed according to the correct standards and within a predetermined time scale. Something that is done because there is motivation will make people happy to do it. People will feel appreciated or recognized.

\section{Cost perception}

Training prepares trainees to take a path specific actions depicted by the technology and organization of the place work, and help participants improve performance in their activities especially regarding understanding and skills. Lee \& Neale (2012), cost is the sacrifice of economic resources measured in the form of money, which has occurred, is occurring, or is likely to occur for a specific purpose. The cost of education is the total financial sacrifice that students pay for the benefit of studying from the beginning to the end of the course (Berlinasari \& Erawati, 2017). This understanding means that the perception of training cost is the student's interpretation of the amount of cost that must be incurred for participating in the competency test training.

\section{Perceived ease of use}

Variable this convenience can be called as perceived easy of use (Nysveen et al., 2005). Davis (1989) ease of useperceived ease of use defined as the extent of a person believe that using a technology will be free of effort.Perceived ease of use is the level where someone believes that information technology is easy to understand (Syaninditha \& Setiawan, 2017). This means that perceived ease of use is the belief in ease of use, that is, the degree to which the user believes that the technology/ system can be used easily and is free from problems. The perception of ease of use is a belief about the decision-making process (Romadloniyah \& Prayitno, 2018). The intensity of use and interaction between the user and the system can also indicate the ease of use. Perception ease of use will reduce effort (both time and effort) someone in studying information technology.

Surifah, et al. (2016), someone who has an intention in an object tends to pay more attention or feel happier to that object. This limitation further clarifies the meaning of intention concerning one's attention. Attention is the selection of a stimulant from the many stimulants that can override a person's acceptance mechanism. Humans, certain problems or situations are stimulants that come to a person's acceptance mechanism, because at any given time only one stimulant can be realized. Of the many stimulants, one must be chosen. This stimulant was chosen because he realized that he had an intention, so he paid attention. The awareness that causes attention to arising is called intention.

\section{Perceived usefulness}

Davis (1989) usefulness is the level of one's trust that the use of a special system would be improve job performance. The process of seeking information through a sensing tool is then selected, organized, and interpreted so that the information it receives becomes a meaningful picture, that is perception (Laksana, et al, 2015). Perception of usefulness is a level of one's belief if the usefulness of a certain system will be able to increase one's performance (Syaninditha \& Setiawan, 2017). From this definition, it is known that perceived usefulness is a belief about the decision-making process. If a person believes that a system is useful then he will use it. Conversely, if someone believes that the information system is less useful then he will not use it. Individual acting on his perceptions regardless of whether the perception is accurate or inaccurate in describing reality (Langelo, 2013).

\section{Hypothesis}

H1: motivation has a direct effect on student intention in participating in the competency test training.

$\mathrm{H} 2$ : The perception of training cost has a direct effect on student intention in participating in the competency test training. 
H3: perceived ease of use has a direct effect on student intention in participating in the competency test training.

H4: perceived usefulness has a direct effect on student intention in participating in the competency test training

\section{METHOD}

This type of research is explanatory research, which the cause effect correlation between variables (independent and dependent) through hypothesis test. The research object was students of the Management Study Program, Economics Faculty, Semarang University. Because the population is not known, sampling is done using the following formula:



Information:

$\mathrm{n} \quad=$ Sample Size

$\mathrm{Za} / 2$ = Standard value lists outside the standard normal how the confidence level is (a) $95 \%$.

e $\quad=$ the level of provision used by suggesting the maximum error magnitude of $20 \%$.

The number of samples was 96 students. The sampling technique in this study was systematic sampling method, with the criteria: students of the Management Study Program who are active in the Economics Faculty and have an intention in participating in the Competency Training.

\section{Instrument Test}

\section{Validity Test}

Ghozali (2016) states that the validity test is a measuring tool used to measure whether a questionnaire is valid or not. A questionnaire is said to be valid if the questions on the questionnaire are able to reveal something that can be measured by the questionnaire. If $r$ count $>$ from $r$ table and the value is positive then the question or indicator item is valid and if $r$ count $<r$ table then the question or indicator is declared invalid.

\section{Reliability Test}

Ghozali (2016) states that reliability is actually a tool for measuring a questionnaire which is an indicator of a variable or construct. A questionnaire is said to be reliable or reliable if someone's answer to a question is consistent or stable over time. AlphaCronbach technique will show that an instrument can be said to be reliable or reliable if it has a reliability coefficient or alpha of 0.6 or more.

\section{t Statistical Test}

Ghozali (2016) revealed that the $t$ statistical test shows how far the influence of one independent variable is on the dependent variable. Testing is done by using $5 \%$ acceptance or rejection of the hypothesis with the following criteria:

a) if the significant value $>0.05$ then the hypothesis is rejected (the regression coefficient is not significant). This means that partially the independent variable does not have a significant effect on the dependent variable.

b) If the significant value $<0.05$, the hypothesis is accepted (significant regression coefficient). This means that partially the independent variable has a significant effect on the dependent variable.

\section{Determination Coefficient Test}

Ghozali (2016) states that the coefficient of determination (R2) essentially measures how far the model's ability to explain the dependent variable. The value of determination is between zero and one. (R2) which is small means that the ability of the independent variables to explain the variation in the dependent variable is very limited.

\section{RESULTS AND DISCUSSION}

\section{Validity and Reliability Tests}

The validity test shows the extent to which measuring instruments are used to measure what is being measured (Ghozali, 2016). Decision making is based on the value of ${ }^{T}$-count (Corrected item-total Correlation) $>{ }^{T}$-table of 0.1689 , for $\mathrm{df}=96-2=94=$ 0.05 , the item/ question is valid and vice versa.

A reliability test is a tool for measuring a questionnaire which is an indicator of a variable or constructs. A questionnaire is said to be reliable or good if someone's answer to a statement is consistent or stable over time (Ghozali, 2016). The instrument reliability coefficient is intended to see the consistency of the answers to the statement items given by the respondent.Alpha-Cronbach technique will show that an instrument can be said to be reliable or reliable if it has a reliability coefficient or alpha of 0.6 or more (Ghozali, 2016). Based on Table 2, it can be said that all questions are valid and reliable.

\section{Multiple Linear Regression Analysis}

Based on table 3 , the regression equation is as follows:

$\mathrm{Y}($ intention $)=$

$\mathrm{X} 1$ (Motivation) $+\mathrm{X} 2$ (Cost Perception) + X3 (Perceived Ease of use) + X4 (Perceived Usefulness) 
Table 2. Validity and Reliability Tests

\begin{tabular}{ccccc}
\hline & $\begin{array}{c}\text { Scale Mean if Item } \\
\text { Deleted }\end{array}$ & $\begin{array}{c}\text { Scale Variance if Item } \\
\text { Deleted }\end{array}$ & $\begin{array}{c}\text { Corrected Item-Total } \\
\text { Correlation }\end{array}$ & $\begin{array}{c}\text { Cronbach's Alpha if Item } \\
\text { Deleted }\end{array}$ \\
\hline x1.1 & 75,91 & 52,212 & 0,401 & 0,828 \\
x1.2 & 75,76 & 51,11 & 0,537 & 0,822 \\
x1.3 & 75,63 & 53,1 & 0,371 & 0,829 \\
X1.4 & 75,94 & 48,543 & 0,631 & 0,816 \\
X2.1 & 75,74 & 55,9 & 0,845 \\
X2.2 & 75,72 & 54,773 & 0,841 \\
X2.3 & 75,76 & 54,205 & 0,187 & 0,837 \\
X3.1 & 75,39 & 51,503 & 0,181 & 0,825 \\
X3.2 & 76,2 & 46,624 & 0,814 \\
X3.3 & 75,93 & 50,195 & 0,471 & 0,824 \\
X3.4 & 76,09 & 48,065 & 0,629 & 0,819 \\
X4.1 & 76,33 & 49,235 & 0,467 & 0,826 \\
X4.2 & 75,93 & 52,763 & 0,559 & 0,833 \\
X4.3 & 76 & 50,989 & 0,444 & 0,824 \\
X4.4 & 76,16 & 48,744 & 0,278 & 0,815 \\
y1 & 76,29 & 50,84 & 0,468 & 0,822 \\
y2 & 75,91 & 52,549 & 0,651 & 0,829 \\
y3 & 76,05 & 55,039 & 0,538 & 0,833 \\
y4 & 76,09 & 51,054 & 0,355 & 0,827 \\
y5 & 75,6 & 52,389 & 0,25 & 0,412 \\
\hline
\end{tabular}

Source: Primary data processed, 2019

Table 3. Multiple Regression Result

\begin{tabular}{|c|c|c|c|c|c|c|c|c|}
\hline & \multirow{2}{*}{$\begin{array}{c}\text { Model } \\
\text { B }\end{array}$} & \multicolumn{2}{|c|}{$\begin{array}{l}\text { Unstandardized } \\
\text { Coefficients }\end{array}$} & \multirow[t]{2}{*}{$\begin{array}{l}\text { Standardized } \\
\text { Coefficients }\end{array}$} & \multirow[t]{2}{*}{$\mathrm{T}$} & \multirow{2}{*}{$\begin{array}{c}\text { Sig. } \\
\text { Tolerance }\end{array}$} & \multicolumn{2}{|c|}{ Collinearity Statistics } \\
\hline & & Std. Error & Beta & & & & VIF & \\
\hline \multirow[t]{5}{*}{1} & (Constant) & 8,025 & 1,499 & & 5,353 & ,000 & & \\
\hline & Motivation & ,396 & 081 & ,417 & 4,908 & ,000 & ,708 & 1,412 \\
\hline & Cost Perception &,- 041 & ,073 &,- 041 &,- 568 &, 572 & ,972 & 1,029 \\
\hline & Perceived Ease of use &, 153 & 066 & ,216 & 2,322 & 022 &, 591 & 1,692 \\
\hline & Perceived Usefulness & 207 & ,071 & 259 & 2,898 & ,005 & ,638 & 1,567 \\
\hline
\end{tabular}

a. Dependent Variable: intention

Source: Primary data processed, 2019

$Y=0.417 X 1-0.041 X 2+0.216 X 3+0,259 X 4$

This is a deterministic model where the dependent variable is derived from combination of the assumed independent variables encouraging change. Based on the results of the regression equation, it can be concluded that:

1. The regression coefficient for the variable of motivation to attend training has a positive value (0.417) meaning that the higher the motivation to participate in the training, the more intention in participating in the training.
2. The regression coefficient for the perceived cost of participating in the training is negative value $(-0.041)$ meaning that the more expensive the perceived cost of participating in training can reduce intention in participating in the training.

3. The regression coefficient for the perceived ease of participating in the training has a positive value $(0,216)$, meaning that the higher the perceived ease of participating in the training, the more intention in participating in the training.

4. The regression coefficient for the perceived usefulness has a positive value $(0,259)$ meaning 
that the better the perceived usefulness gave to attend the training, the more intention it will be in participating in the training.

\section{Hypothesis Testing}

This test is carried out using a significant level of 0.05 . In this study it is considered not to have high accuracy then using 0.05 and not 0,01 . A significance level of $5 \%$ or 0.05 means that we take the risk of making a wrong decision to reject the correct hypothesis at most $5 \%$ and correct in making decisions at least $95 \%$ (confidence level). In this study, the $\mathrm{t}$ table value is $(\mathrm{n}-\mathrm{k})$ where $\mathrm{n}$ $=96$ and $\mathrm{k}=5$ then $(\mathrm{n}-\mathrm{k}=91)$, so the $\mathrm{t}$ table is 1.662. The $t$ value and $t$-test results are presented in the table, as follows:

Table 4. $t$ value

\begin{tabular}{ccccccc}
\hline d.f & $t_{0.0}$ & $t_{0 . \sigma}$ & $t_{0.025}$ & $t_{0.0}$ & $t_{0.005}$ & d.f \\
\hline 1 & 3,078 & 6,314 & 12,706 & 31,821 & $\begin{array}{c}63, \\
657\end{array}$ & 1 \\
2 & 1,886 & 2,920 & 4,303 & 6,965 & 9,925 & 2 \\
$\ldots$ & & & & & & \\
91 & 1,291 & 1,662 & 1,986 & 2,368 & 2,631 & 91 \\
Inf. & 1,290 & 1,660 & 1,984 & 2,364 & 2,626 & Inf. \\
\hline
\end{tabular}

Source : Aplikasi Analisis Multivariate Dengan Program SPSS (Ghozali)

From 5 the table above it can be seen:

a. The statistical t-test on motivation to participate in training (X1) has a positive and significant effect on the intention in participating the competency training $(\mathrm{Y})$ with a significance level of $0.000<$ 0.05 while the $t$ count is $4.908>t$ table 1.6618 , so it can be concluded that $\mathrm{H} 1$ is accepted.

b. The statistical t-test on perceived cost (X2) has a negative and insignificant effect on the intention in participating the competency training $(\mathrm{Y})$ with a significance level of $0.572>0.05$ while $t$ count - $0.568>\mathrm{t}$ table 1,6618 , so it can be concluded that $\mathrm{H} 2$ is rejected.

c. The statistical t-test on perceived ease of use (X3) has a positive and significant effect on the intention in participating in the competency training $(\mathrm{Y})$ with a significance level of $0.022<$ 0.05 , while $t$ count $2.322>t$ table 1.6618 , so it can be concluded that $\mathrm{H} 3$ is accepted.

d. The statistical t-test on perceived usefulness (X4) has a positive and significant effect on the intention in participating in the competency training $(\mathrm{Y})$ with a significance level of $0.005<$ 0.05 , while t count $2.898>t$ table 1.6618 , so it can be concluded that $\mathrm{H} 4$ is accepted.

\section{Coefficient of Determination $\left(\mathbf{R}^{2}\right)$}

Table 6. The Result of Determination Coefficient Test

\begin{tabular}{llcr}
\hline Model & R & R Square & Adjusted R Square \\
\hline 1 &, $731^{\mathrm{a}}$ &, 535 &, 514 \\
\hline \multicolumn{4}{c}{ Source: Primary data processed, 2019}
\end{tabular}

Table 6 shows the $\mathrm{R} 2$ value of 0.535 , meaning that $53.5 \%$ of the variation of the intention in participating in the competency training can be explained by the independent variables of motivation, perceived cost, perceived ease of use, and perceived usefulness.

\section{The Effect of Motivation on Intention}

Motivation is the factors that exist within a person who can give his behavior to fulfill certain goals. The results of testing the $\mathrm{H} 1$ hypothesis indicate that motivation has a positive and significant effect on intention in participating in competency training. This is proven by the significance level of $0.000<$ 0.05 , while t count $4.908>$ t table 1.668 , which means that the first hypothesis is accepted. From the results of the regression coefficient analysis, the motivation

Table 5. Hypothesis Testing Result

\begin{tabular}{|c|c|c|c|c|c|c|c|c|}
\hline \multirow{2}{*}{\multicolumn{2}{|c|}{$\begin{array}{c}\text { Model } \\
\text { B }\end{array}$}} & \multicolumn{2}{|c|}{ Unstandardized Coefficients } & \multirow[t]{2}{*}{$\begin{array}{c}\text { Standardized } \\
\text { Coefficients }\end{array}$} & \multirow[t]{2}{*}{$\mathrm{T}$} & \multirow{2}{*}{$\begin{array}{c}\text { Sig. } \\
\text { Tolerance }\end{array}$} & \multicolumn{2}{|c|}{ Collinearity Statistics } \\
\hline & & & & & & & & \\
\hline \multirow[t]{5}{*}{1} & (Constant) & 8,025 & 1,499 & & 5,353 &, 000 & & \\
\hline & Motivation & ,396 & 081 &, 417 & 4,908 &, 000 & ,708 & 1,412 \\
\hline & Cost Perception &,- 041 &, 073 &,- 041 &,- 568 &, 572 & ,972 & 1,029 \\
\hline & Perceived Ease of use &, 153 &, 066 & ,216 & 2,322 & 022 &, 591 & 1,692 \\
\hline & Perceived Usefulness & ,207 &, 071 & ,259 & 2,898 &, 005 & ,638 & 1,567 \\
\hline a. & Dependent Varic & tention & & & & & & \\
\hline
\end{tabular}


variable is positive, which means that if motivation increases, the desire to participate in training also increases. The acceptance of this hypothesis is reinforced by the finding that the average score of student intention in participating in the competency training is 332 and is in the high category. This reveals that students have a high intention in participating the competency training because competency training is considered to be able to help the development of the manager's profession, can improve the quality of prospective managers, can help career success in the management profession, and a means of getting a job that provides large financial payments. The high intention in competency training encourages students to take competency training before completing their studies.

The results of this study support the opinion of Robbins (2008) which states that motivation is the willingness to spend a high level of effort towards organizational goals, which is conditioned by the ability of that effort to meet an individual need. A person's motivation starts with a need, desire, and urge to act to achieve a need or goal. This indicates how strong the drive, effort, intensity, and willingness to sacrifice for the achievement of goals. In this case, the stronger the motivation or motivation and enthusiasm, the higher the performance. The results of this study are also following the motivation theory of Hasibuan (2016) which states that motivation is the provision of the driving force that creates a person's enthusiasm for work so that they are willing to work together, work effectively and with integrity with all efforts to achieve satisfaction. Desire can be maximally achieved if motivation goes through a gradual cycle (Surifah, et al, 2016). This research supports Baloglu \& Mc Cleary (1999); Standage, et. al, (2003); Huang \& Hsu (2009); Indriyani (2018); Setyawan \& Iswanaji (2019) studies which stated that motivation affects student intention. Motivation is a basic psychological process (Taghipour \& Dejban, 2013), which activates, guides, and maintains behaviour (Palmer, 2005), as a driving force for the professional growth of personality (Sidorovaa, 2015), an impetus for taking action based on certain needs and desires (Ganesan \& Gaurib, 2012) as well as an important incentive to improve performance (Santisi, et. al, 2014). Different results have been studied by Widyanto \& Fitriana (2016) it states that motivation does not affect intention.

\section{Perception of Cost on Intention}

From the results of the regression coefficient analysis of the training cost variable, negative results were obtained so that in this case it can be said that the higher the cost of training to attend competency training, the more intention in participating in the competency training will decrease. This coefficient indicates the negative and inelastic relationship between the average increase in the total cost of education and the average decrease in the number of students intentioned in participating in the competency training. This negative relationship is following demand theory. The results of this study are following the theory of the perception of training cost from Berlinasari \& Erawati (2017) which states that the cost of education is the total financial sacrifice that students pay for the benefit of studying from the beginning to the end of the course. This is in line with Gul, et. al. (1989); Eline (2009); Sapitri \& Yaya (2015); Berlinasari \& Erawati (2017) which shows that costs affect intention. On the other hand, it is different from Zyl (2011); Katti \& Mutmainah (2014) research, namely that the cost of PPAk education does not significantly affect the intention of students in attending PPAk education. The results are different from Denziana \& Febriani (2017) research which stated that the cost of PPAk education affects significantly the intention of students in attending PPAk education.

\section{Perceived Ease of Use on Intention}

From the analysis of the regression coefficient of the perception of ease of use variables, positive results were obtained, which means that if students see the ease of competency training, the intention in participating in the competency training will also be greater. The acceptance of this hypothesis is reinforced by the finding that the average score of student intention in participating in the competency training is 346 and is in the high category. This reveals that students have a high intention in participating in competency training because competency training is considered easy and can improve student quality. The high intention in competency training makes it easy for students to take competency training before completing their studies. This research is following the theory of perceived ease of use from Romadloniyah \& Prayitno (2018), which states that use is a belief about the decision-making process. This research is in line with Davis (1989); Nysveen et al. (2005); Langelo (2013); Alharbi \& Drew (2014); Prathama \& Sahetapy, 2019; Witami \& Suartana (2019); which shows that perceived ease has a positive effect on intention.

\section{Perceived Usefulness on Intention}

From the results of the regression coefficient analysis of the user variable, positive results were 
obtained so that in this case it can be said that the higher the usefulness of participating in the competency training, the intention in participating in the competency training will also increase. The acceptance of this hypothesis is reinforced by the finding that the average score of student intention in participating in the competency training is 339 and is in the high category. This reveals that students have a high intention in participating in competency training because competency training is considered useful and can help career success and a means of getting a prestigious job. The high intention in competency training encourages students to take competency training before completing their studies. This research is following the theory of perceived usefulness from Syaninditha \& Setiawan (2017) which states that perceived usefulness is a level of one's belief if the use of a certain system will be able to increase one's performance. This is in line with Davis (1989); Nysveen et al. (2005). Langelo (2013); Lu, et. al. (2009); Lou, et. al (2005); Alharbi \& Drew (2014); Witami \& Suartana (2019) researches which showed that perceived usefulness affects intention.

\section{CONCLUSION}

Motivation has a positive and significant effect on intention in participating in competency training, which means that if motivation increases, the desire to take part in training also increases. This is reinforced by the finding that the average score of student intention in participating in competency training falls into the high category.

The training costs obtained negative results so that in this case it can be said that the higher or higher the cost of training to attend competency training, the intention in participating in competency training actually decreases. This negative relationship is in accordance with demand theory.

The perception of ease of obtaining positive results means that if students see the ease of competency training, the intention in participating in competency training will also be greater. The average score of student intention in participating in competency training is in the high category.

The benefits are obtained positive results so that in this case it can be said that the higher or higher the benefits of participating in competency training, the intention in participating in competency training will also increase.

The implication: (1) The quality of the training needs to be improved, namely by using a lot of case study questions and practice questions. (2) The material is kept as simple as possible so that it is easily understood by the trainees. (3) Cooperating with institutions that issue competency training tests.

For further researchers it is hoped that it can expand the scope of the respondent, it is better if you add other variables that can influence student interest, such as: variable income of parents, subjective norms.

\section{REFERENCE}

Agarwal, R. \& Karahanna, E. (2000). Time flies when you're having fun: cognitive absorption and beliefs about information technology usage. MIS Quarterly. (24), 4. 665-696.

Aidha, Z. (2016). Pengaruh Motivasi Terhadap Minat Berwirausaha Mahasiswa Fakultas Kesehatan Masyarakat Universitas Islam Negeri Sumatera Utara. Jurnal Jumantik. 1,(1), 42-59. DOI: http://dx.doi.org/10.30829/ jumantik.v1il.1015

Ajzen, I. (1991). The Theory of Planned Behavior. Organizational Behavior and Human Decision Processes, 50: 179-211. https://doi. org/10.1016/0749-5978(91)90020-T.

Alharbi, S. \& Drew, S. (2014). Using the technology acceptance model in understanding academics' behavioural intention to use learning management systems. International Journal of Advanced Computer Science and Applications, 5,(1), 143- 155.

Baloglu, S. \& McCleary, K.W. (1999). A model of destination image formation. Annals of Tourism Research, 26,(4), 868-897

Berlinasari, M \& Erawati, NMA. (2017). Pengaruh Motivasi, Biaya Pendidikan Dan Lama Pendidikan Pada Minat Mahasiswa Akuntansi Mengikuti PPAK. E-Jurnal Akuntansi Universitas Udayana. 21,(1), 447-476.

Crompton, J.L. (1979). Motivations for pleasure vacation. Annals of Tourism Research, 6,(4), 408-424.

Davis, F.D. (1989). Perceived usefulness, perceived ease of use, and user acceptance of information technology. Management Information Systems Research Center, University of Minnesota, 13,(3), 319-340

Denziana, A. \& Febriani, RF. (2017). Pengaruh Motivasi, Persepsi Biaya Pendidikan Dan Lama Pendidikan Terhadap Minat Mahasiswa Akuntansi Untuk Mengikuti Pendidikan Profesi Akuntansi (PPAk) (Studi Kasus Pada Perguruan Tinggi di Bandar Lampung). Jurnal Akuntansi \& Keuangan. 8,(2), 56-66. DOI: http://dx.doi.org/10.36448/jak.v8i2.946 
Eline, G. (2009). Factors Affecting the Motivation on Interest Students to Participate an Accounting Profession Education. African Journal of Businiess Etich, 4,(1), 46-55

Ganesan, R. \& Gaurib, P. (2012). G-Square: Development of an empirical model to map motivators to deeply embedded life interests as a strategy for improving employee performance through job sculpting. Procedia - Social and Behavioral Sciences, 58,(2012), 331-339.

Ghozali, I. (2016). Aplikasi Analisis Multivariete Dengan Program IBM SPSS 23 (Edisi 8). Cetakan ke VIII. Semarang: Badan Penerbit Universitas Diponegoro.

Gul, F.A. Andrews, B.H. Leong, S.C. \& Ismail, Z. (1989) Factors influencing choice of discipline of study -accountancy, engineering, law and medicine. Accounting and Finance, 29,(2), 93-101

Hasibuan, Malayu S.P.. (2017). Manajemen Sumber Daya Manusia. Edisi Revisi. Jakarta: Bumi Aksara.

Huang, S. \& Hsu, C.H.C. (2009). Effects of travel motivation, past experience, perceived constraint, and attitude on revisit intention. Journal of Travel Research, 48,(1), 29-44.

Indriyani, S. (2018). Pengaruh Motivasi Dan Pengetahuan Undang-Undang No.5 Tahun 2011 Tentang Akuntan Publik Terhadap Minat Mahasiswa Akuntansi Untuk Mengikuti Pendidikan Profesi Akuntansi (Studi Kasus Pada Mahasiswa Akuntansi Universitas Riau, Universitas Islam Negeri Sultan Syarif Kasim Riau, Universitas Islam Riau dan Universitas Lancang Kuning). Jurnal Online Mahasiswa. 1,(1), 1-12.

Katti, S.W.B. \& Mutmainah. (2014). Analisis Pengaruh Motivasi Kualitas, Biaya Pendidikan, Dan Lama Studi Terhadap Minat Mahasiswa Akuntansi Untuk Mengikuti Pendidikan PPAK (Studi Kasus Pada Universitas Merdeka Madiun). Ekomaks. 3,(2), 109-122.

Kotler, P \& Keller, K.L, (2016). Marketing Managemen, 15th Edition, Pearson Education,Inc.

Laksana, G.B., Astuti, E.S. \& Dewantara, R.Y. (2015). Pengaruh Persepsi Kemanfaatan, Persepsi Kemudahan Penggunaan, Persepsi Resiko Dan Persepsi Kesesuaian Terhadap Minat Menggunakan Mobile Banking (Studi Pada Nasabah Bank Rakyat Indonesia (BRI) Kantor Cabang Rembang, Jawa Tengah). Jurnal Administrasi Bisnis (JAB), 26,(2), 1-8.
Langelo, A.S.E. (2013). Perceived Usefulness, Perceived Ease Of Use, Perceived Risk Impact To Lecturers' Internet Banking Adoption. International Business Administration (IBA), 1,(4),1570-1580.DOI:https://doi.org/10.35794/ emba.v1i4.2962

Lee, R. \& Neale, L. (2012). Interactions And Consequences Of Inertia And Switching Cost. Journal Of Service Marketing. 26,(5), 365-374.

Lou, H., Chau, P.Y., \& Li, D. (2005). Understanding individual adoption of instant messaging: An empirical investigation. Journal of the Association for Information Systems. 6,(4). 5

Lu, Y., Zhou, T. \& Wang, B. (2009). Exploring Chinese users' acceptance of instant messaging using the theory of planned behavior, the technology acceptance model, and the flow theory. Computers in Human Behavior. 25,(1). 29-38.

Lundberg, C., Gudmundson, A. \& Andersson, D. (2009). Herzberg's Two-Factor Theory of work motivation tested empirically on seasonal workers in hospitality and tourism. Tourism Management, 30,(6), 890-899

Mangkunegara, A.P. (2016). Manajemen Sumber Daya Manusia Perusahaan. Bandung : PT. Remaja Rosdakarya.

Mulyadi. (2016). Sistem Informasi Akuntansi. Jakarta: Salemba Empat.

Nysveen, H., Pedersen, P. \& Thorbjornsen, H. (2005). Intentions to use mobile services: Antecedents and cross-service comparisons. Journal of Academy of Marketing Science. 33,(3). 330-346.

Palmer, D. (2005). A Motivational View of Constructivist informed Teaching. International Journal of Science Education, 27,(15), 1853-1881.

Prathama, F., \& Sahetapy. WL. (2019). Pengaruh Kemudahan Penggunaan Aplikasi Dan Kepercayaan Konsumen Terhadap Minat Beli Ulang Konsumen E-Commerce Lazada. Jurnal AGORA. 7,(1), 1-6.

Robbins, S. (2008). Perilaku Organisasi, Jilid I dan II, alih Bahasa: Hadyana Pujaatmaja. Jakarta: Prenhallindo.

Romadloniyah, A.L. \& Prayitno, D.H. (2018). Pengaruh Persepsi Kemudahan Penggunaan, Persepsi Daya Guna, Persepsi Kepercayaan, Dan Persepsi Manfaat Terhadap Minat Nasabah Dalam Menggunaan E-Money Pada Bank BRI Lamongan. Jurnal Penelitian Ekonomi dan Akuntansi. III,(2), 699-711. 
DOI: http://dx.doi.org/10.30736\%2Fjpensi. v3i2.164

Santisi, G., Magnano, P., Hichy, Z. \& Ramaci, T. (2014). Metacognitive strategies and work motivation in teachers: an empirical study. Procedia - Social and Behavioral Sciences, 116, (2014), 1227-1231

Sapitri, Z, \& Yaya, R. (2015). Faktor-Faktor Yang Berpengaruh Terhadap Minat Mahasiswa Untuk Mengikuti PPAK. Jurnal Ilmiah Universitas Muhammadiyah Yogyakarta. 16,(1), 46-61.

Setyawan, S. \& Iswanaji, C.. (2019). Pengaruh Motivasi Akuntan Terhadap Minat untuk Memperoleh Gelar Chartered Accountant (CA) di Wilayah Yogjakarta. Jurnal Riset Akuntansi Dan Keuangan, 7,(2), 327342. DOI: https://doi.org/10.17509/jrak. v7i2.16855

Sidorovaa, T. (2015). The Social and Psychological Determinants of Faculty Members Work Motivation. Procedia - Social and Behavioral Sciences, 186, (2015), 1188 - 1191

Standage, M., Duda, J., \& Ntoumanis, N. (2003). A model of contextual motivation in physical education: Using constructs from selfdetermination and achievement goal theories to predict physical activity intentions. Journal of Educational Psychology, 95, (1), 97-110

Surifah, Mustiati, E., Syaifullah, MZ. \& Bowo, A.N.A. (2016). Pengaruh Motivasi Terhadap Minat Mahasiswa Mengikuti Pendidikan
Profesi Akuntansi. Jurnal Kependidikan. 46, (2), 246-258. DOI: https://doi.org/10.21831/ jk.v46i2.9615

Syaninditha, S.A.P \& Setiawan, P.E. (2017). Pengaruh Persepsi Kegunaan, Persepsi Kemudahan, Faktor Sosial, Dan Kondisi Yang Memfasilitasi Terhadap Minat Penggunaan E-Filling. E-Jurnal Akuntansi Universitas Udayana. 21, (1), 86-115.

Taghipour, A. \& Dejban, R. (2013). Job Performance: Mediate Mechanism of Work Motivation. Procedia - Social and Behavioral Sciences, 84,(2013), 1601-1605

Vijayasarathy, Leo, R. (2003). Predicting consumer intentions to use on-line shopping: The case for an augmented technology acceptance model. Journal of Information and Management. 41. 747-762

Widyanto, E.A. \& Fitriana, R. (2016). Pengaruh Motivasi Terhadap Minat Mengikuti Ujian Chartered Accountant (Ca) Indonesia. JURNAL EKSIS. 12,(1), 3214-3345.

Witami, D.A.D. \& Suartana, I.W. (2019). Pengaruh Persepsi Kegunaan, Kemudahan Penggunaan dan Risiko Terhadap Minat Mahasiswa Menggunakan Sistem Blockchain. E-Jurnal Akuntansi. 28,(2), 1346-1376. DOI: https:// doi.org/10.24843/EJA.2019.v28.i02.p21

Zyl, V. (2011). Why some Student Choose To Become Chartered Accounta ejns (And Others Do Not). Meditari Accountancy Research, 19, (1), 56-74 